\title{
Solar cell system simulation using Matlab-Simulink
}

\author{
Roshen Tariq Ahmad Hamdi \\ Energy and Renewable Energy Technology Center \\ University of Technology, \\ Baghdad,IRAQ \\ 11019@uotechnology.edu.iq
}

\begin{abstract}
: representation and demonstrating of sun based cells is critical for the photovoltaic framework configuration keeping in mind the end goal to get best productivity from the sun and decrease the shore of sun based cell framework. The fundamental subject of this article concentrates on a software created in MATLAB/Simulink of photovoltaic unite. This software depends on numerical equation and is depicted through a comparable The electric circuit is integrated into the photocurrent source, a diode, and a set of series and parallel resistors. The reenactment utilized as a part of this article to get the attributes (I-V), and afterward we will concentrate the impact of each parameter on the curve. The created demonstrate permits the expectation of photo-voltaic unite conduct beneth various physical and characteristic parameters. The unite can likewise be utilized to separate the physical parameters for a given sun based PV cell as an element of temperature and sunlight based irradiance.
\end{abstract}

Keywords: Matlab-Simulink, PV, solar cell model, solar array model

\section{INTRODUCTION}

The improvement of new vitality sources are ceaselessly upgraded due to the basic circumstance of the synthetic chemical powers. Therefore, the inexhaustible vitality sources turned into a more critical patron to the aggregate vitality devoured on the planet. Truth be told, the interest for sunlight based vitality has expanded by $20 \%$ to $25 \%$ in the course of recent years. With a specific end goal to get advantage from the utilization of PV systems, explore exercises are being led trying to increase promote change in their cost, productivity and unwavering quality, therefore numerical displaying of sun powered cells is fundamental for any operation yield improvement.

An exact learning of sun based cell variables from exploratory information is of fundamental significance for the outline of sun-powered cells and for the evaluations of their execution. The electrical proportional circuit is a helpful and regular route in most reproduction studies. The five variables of enthusiasm for the proportionate circuit are the photocurrent $\left(\mathrm{I}_{\mathrm{PV}}\right)$, series resistance $\left(R_{S}\right)$, diode immersion current $\left(I_{0}\right)$, shunt resistance $\left(\mathrm{R}_{\mathrm{SH}}\right)$ and the idealism consider $(\mathrm{A})$. The present relation voltage of a sun powered cell is depicted by a scientific condition both certain what's more, nonlinear.

In this work, MATLAB script document program has been utilized to register the five variables of the a unite diode model of lit up sun powered cells. The outcomes acquired by reenactment demonstrate the consistency between the information and got the parameters given by the maker, to be specific: short circuit current ( $\left.\mathrm{I}_{\mathrm{SC}}\right)$, open circuit voltage $\left(\mathrm{V}_{\mathrm{OC}}\right)$ and most extreme power $\left(\mathrm{P}_{\max }\right)$. For example, these variables can be utilized for quality control amid creation or to give bits of knowledge into the operation of the gadgets [1, 2, 3, 4 and 5].

\section{ELECTRIC AND MATHEMATICAL MODELING OF SOLAR CELL}

A photovoltaic cell can be demonstrated as a present electrical current source PN associated in shunt with a diode. Current source delivers a steady present. This current is corresponding to the power of the light hit the upon cell. Photovoltaic frameworks influenced specifically with climate conditions and sun oriented radiation. The execution of a sun oriented cell is expected to comprehend the relationship amongst's current and voltage of the cell [6].

The ideal proportional circuit of a PV cell (Duffie and Beckman, 1980) is appeared in Figure 1. It incorporates a current source, a diode, a series arrangement resistance $\left(R_{s}\right)$ and a shunt resistance $\left(R_{s h}\right)$, these two resistances added because there is no ideal solar cell in practice [7, 8].

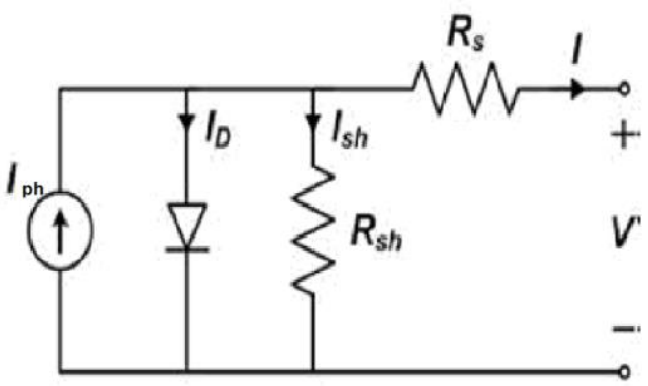

Figure 1 Diode model of the PV cell

With the identical circuit figure 1 and utilizing Kirchhoff's law, we get the accompanying condition for the load current $[9,10]$ :

$I=I_{p h}-I_{d}-I_{s h}$

Where:

$\mathrm{I}=\mathrm{O} / \mathrm{P}$ current (Amp.)

$\mathrm{I}_{\mathrm{ph}}=$ Photo produced current (Amp.)

$\mathrm{I}_{\mathrm{d}}=$ Diode current (Amp.)

$\mathrm{I}_{\mathrm{sh}}=$ Shunt resistance current (Amp.)

The current passes these components is administered by the voltage crosswise over them:

$V_{j}=V+I R_{s}$ 
where

$\mathrm{V}=$ voltage over the yield terminals (volt)

$\mathrm{V}_{\mathrm{j}}=$ voltage across both diode and resistor $\mathrm{R}_{\mathrm{SH}}$ (volt)

$\mathrm{I}=$ output current (ampere)

$\mathrm{R}_{\mathrm{s}}=$ series resistance $(\Omega)$

By the Shockley diode condition, the current occupied through the diode is:

$I_{d}=I_{o}\left\{e^{\left[\frac{V_{j}}{n \times V_{T}}\right]}-1\right\}$

Where:

$\mathrm{I}_{\mathrm{O}}=$ is the diode reverse saturation current.

$\mathrm{V}_{\mathrm{T}}=$ is the thermal voltage given by:

$V_{T}=\frac{k \times T}{q}$

$\mathrm{V}_{\mathrm{T}}$ the thermal voltage at $25^{\circ} \mathrm{C} \mathrm{VT} \cong 0.0259$ volt $\mathrm{n}=$ Diode ideality factor (unitless, usually between 1 and 2 for a single junction cell).

$\mathrm{q}=$ Electron charge $\left(1.602 \times 10^{-19} \mathrm{C}\right)$.

$\mathrm{k}=$ Boltizmann's constant $\left(1.381 \times 10^{-23} \mathrm{~J} / \mathrm{K}\right)$.

$\mathrm{T}=$ Operating temperature.

Using Ohm's law, the current occupied in the shunt resistor is:

$I_{s h}=\frac{V_{j}}{R_{s h}}=\frac{V+I R_{s}}{R_{s h}}$

Where:

$\mathrm{R}_{\mathrm{sh}}=$ Shunt resistance $(\Omega)$.

Replace these values into the first equation creates the trademark condition of a sun-oriented cell, which communicates sun powered cell variables to the yield volt and current $[11,12]$ :

$$
I=I_{p h}-I_{o}\left\{e^{\left(\frac{V+I R_{s}}{n \times V_{T}}\right)}-1\right\}-\frac{V+I R_{s}}{R_{s h}}
$$

Photo current is administered by the following equation:

$$
I_{p h}=\left[I_{s h}+K_{i}(T-298)\right] \times\left(\frac{G}{1000}\right)
$$

Where:

$\mathrm{I}_{\mathrm{sc}}=$ Short circuit current (A).

$\mathrm{K}_{\mathrm{i}}=$ Solar cell short circuit current temperature coefficient $=0.0017$

$\mathrm{T}=$ Operating temperature (Kelvin).

$\mathrm{G}=$ Irradiance $\left(\mathrm{mW} / \mathrm{m}^{2}\right)$ in this equation irradiance divide by 1000 to get $\left(\mathrm{W} / \mathrm{m}^{2}\right)$.

There are two states for the solar cell, the first one is open circuit and the second one is short circuit.

At the point if the cell is worked at open circuit, $\mathrm{I}=0$ and the voltage over the yield terminals is characterized as the open-circuit voltage $\mathrm{V}_{\mathrm{OC}}$. Expecting the parallel resistance is sufficiently large to disregard the last term of the trademark condition, the open-circuit voltage $\mathrm{V}_{\mathrm{OC}}$ is: At short circuit condition, all the current will go over the short out so $\mathrm{I}_{\mathrm{ph}}$ is equivalent to $\mathrm{I}_{\mathrm{sc}}$.

$$
I=I_{p h}-I_{d}
$$

Where:

$\mathrm{I}_{\mathrm{d}}=$ as shown in equation 3

So

$$
I=I_{s h}-I_{o}\left\{e^{\left[\frac{V_{j}}{n \times V_{T}}\right]}-1\right\}
$$

We can decide the invert immersion current I0 by setting $\mathrm{I}=$ zero (situation when no yield current) and that case called open circuit.

At short circuit $\mathrm{I}=0$ and $\mathrm{V}=\mathrm{V}_{\mathrm{oc}}$

Where:

$\mathrm{V}_{\mathrm{oc}}=$ output voltage at open circuit state.

In addition, that cause the all current go through the diode since the shunt resistance is high as clarified already so.

$$
\begin{aligned}
& o=I_{p h}-I_{o} \times\left[e^{\frac{(q \times V)}{\left(N_{s} \times k \times n \times T\right)}}-1\right] \\
& I_{o}=\frac{I_{s h}}{\left[e^{\frac{(q \times V)}{\left(N_{s} \times k \times n \times T\right)}}-1\right]}
\end{aligned}
$$

What's more, the current in the shunt resistance acquired from the accompanying condition:

$$
I_{s h}=I_{o}\left(\frac{T}{T_{r e f}}\right)^{3} \times\left[e^{\left(\frac{q \times E_{g}\left(\frac{1}{T_{r e f}}-\frac{1}{T}\right)}{k \times n}\right)}\right]
$$

Where:

$\mathrm{T}_{\text {ref }}=$ Reference temperature (Kelvin).

$\mathrm{E}_{\mathrm{g}}=$ Band gap for Silicon.

For a photovoltaic array or cluster containing $\mathrm{N}_{\mathrm{s}}$ cells in series, $\mathrm{N}_{\mathrm{p}}$ cells in parallel and expecting all cells are indistinguishable and under uniform and equivalent irradiance and temperature (i.e., generate equal current and voltage).

$$
I_{\bmod u l e}=N_{p} \times I_{\text {cell }} \text { and } V_{\bmod u l e}=N_{s} \times V_{\text {cell }}
$$

The last single diode condition for a module or exhibit gets to be: 


$$
I=\left(N_{p} \times I_{p h}\right)-N_{p} \times I_{s h}\left[e^{\left(\frac{q\left(V+\left(I_{s}\right)\right)}{\left(N_{s} \times n \times k \times T\right)}\right)}-1\right]-\frac{V+I R_{s}}{R_{s h}}
$$

\section{SOLAR CELL SIMULATION}

Conditions depicted in past segment are demonstrated to acquire IV and PV Characteristics of a solitary diode sun powered cell module. The reproduction incorporates numerous subsystems: one that figures the PV cell working and reference temperature ( $\mathrm{T}$ and $\mathrm{T}_{\text {ref }}$ ), the second ascertain $\mathrm{I}_{\mathrm{ph}}$ (Photo cell current), the third one compute $I_{0}$ (Diode turn around immersion current), the fourth one ascertain Ish (Current in shunt resistance) while the last one figure the aggregate yield current and aggregate yield voltage (I, V) [13, 14]. All the blocks obtained by using Matlab-Simulink to represent all the equations explained in previous section by using source, sinks and math's relation.

Some parameters used in this research have been assumed in order to accomplish the work and they are shown in table 1 below.

Table 1: Photovoltaic Model Parameters

\begin{tabular}{|c|c|}
\hline Parameters & Value \\
\hline $\mathrm{R}_{\mathrm{s}}$ & $0.002(\Omega)$ \\
\hline $\mathrm{R}_{\mathrm{sh}}$ & $100000(\Omega)$ \\
\hline $\mathrm{K}$ & 0.0017 \\
\hline $\mathrm{I}_{\mathrm{sc}}$ & $3.8(\mathrm{~A})$ \\
\hline $\mathrm{N}_{\mathrm{s}}$ & 36 \\
\hline $\mathrm{N}_{\mathrm{p}}$ & 1 \\
\hline $\mathrm{V}$ & $21.2(\mathrm{~V})$ \\
\hline $\mathrm{E}_{\mathrm{g}}$ & 1.1 \\
\hline $\mathrm{n}$ & 1.1 \\
\hline $\mathrm{K}_{\mathrm{i}}$ & $1.381 \times 10^{-23}(\mathrm{~J} / \mathrm{K})$ \\
\hline $\mathrm{q}$ & $1.602 \times 10^{-19}(\mathrm{C})$ \\
\hline $\mathrm{I}_{\mathrm{sc}}$ & $3.8(\mathrm{~A})$ \\
\hline $\mathrm{T}$ & $\begin{array}{c}25-30-35\left(\mathrm{C}^{\mathrm{o}} \text { for }\right. \\
\text { many test })\end{array}$ \\
\hline $\mathrm{G}$ & $\begin{array}{c}300-500-700 \\
\left(\mathrm{~mW} / \mathrm{m}^{2} \text { for many }\right. \\
\text { test })\end{array}$ \\
\hline
\end{tabular}

\subsection{TEMPERATURE MODULE $\left(\mathrm{T}, \mathrm{T}_{\mathrm{REF}}\right)$}

One of the simulation blocks is the temperature (in Kelvin) as shown in figure 2. The subsystem contain four blocks, the input is the operating temperature in degree centigrade and the two outputs is the temperature (T) in Kelvin and the reference temperature $\left(\mathrm{T}_{\mathrm{ref}}\right)$ in Kelvin's too. The subsystem job is to convert the temperature units, the reference temperature assumed to be 25 Co which is room temperature, figure 3 shows details of the temperature subsystem.

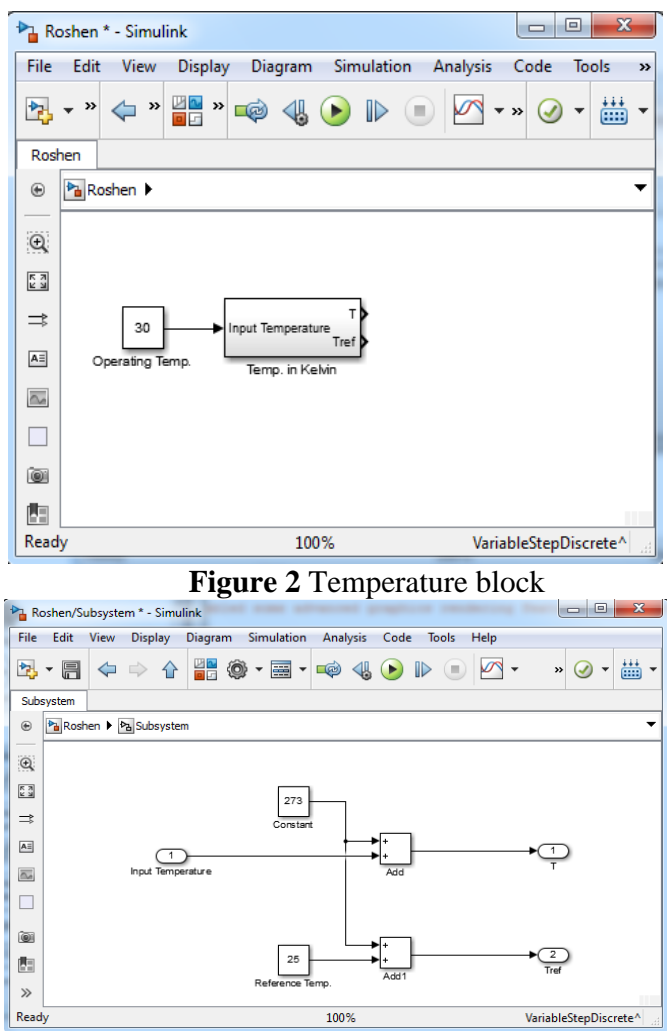

Figure 3 Details of the temperature subsystem

\subsection{PHOTO CELL CURRENT MODULE (I $\left.\mathrm{I}_{\mathrm{PH}}\right)$}

This block represents the photocell current according to equation 7 as shown in figure 4 . The inputs are irradiance $\left(\mathrm{mW} / \mathrm{m}^{2}\right)$, short circuit current $(\mathrm{A})$, reference temperature (Kelvin) and operating temperature (Kelvin) while the output is the photocell current in (A), the details of this block shown in figure 5 , which is the subsystem of the block.

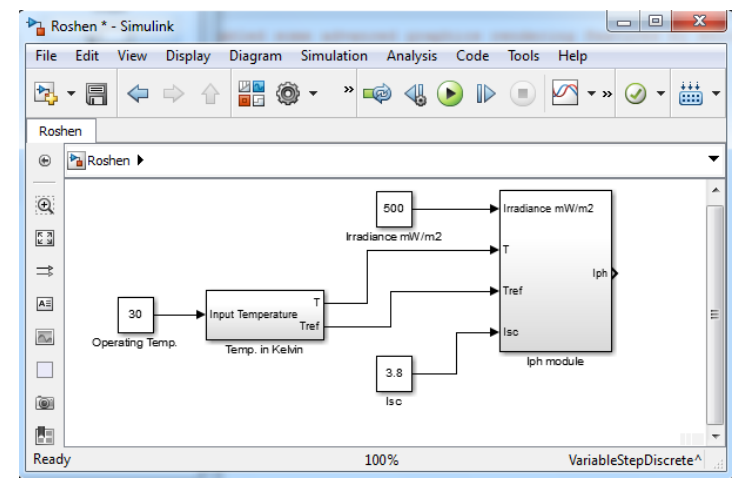

Figure 4 Photocell current module in the system 


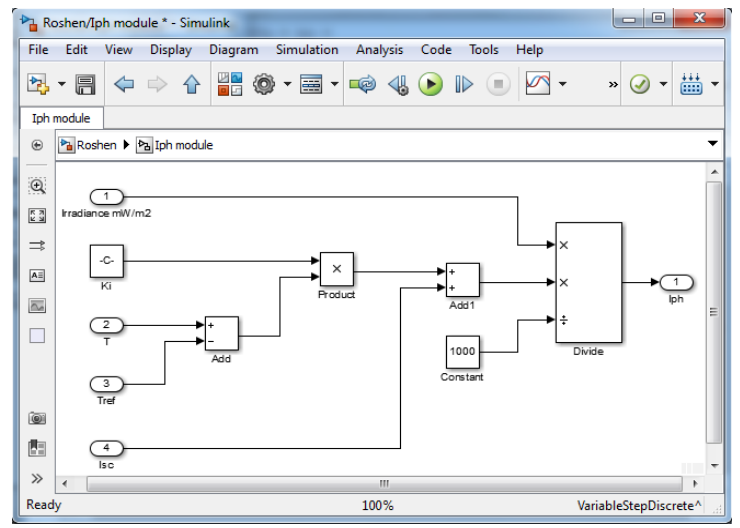

Figure 5 Photocell current subsystem module

\subsection{DIODE REVERSE SATURATION CURRENT MODULE ( $\left.\mathbf{I}_{0}\right)$}

This block represents the diode reverse saturation current according to equation 8 as shown in figure 6 . The inputs are short circuit current (A) and operating temperature (Kelvin) and the output is the diode reverse saturation current (A), the parameters used in this block is electron charge, voltage across the output terminal, number of series cells, Boltzman'n constant and diode ideality factor. The details of this block shown in figure 7 , which is the subsystem of the block.

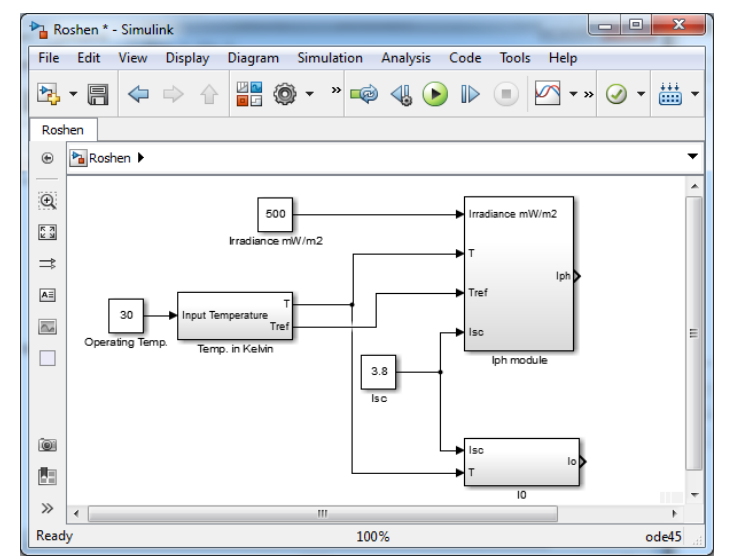

Figure 6 Diode reverse saturation current module in the system

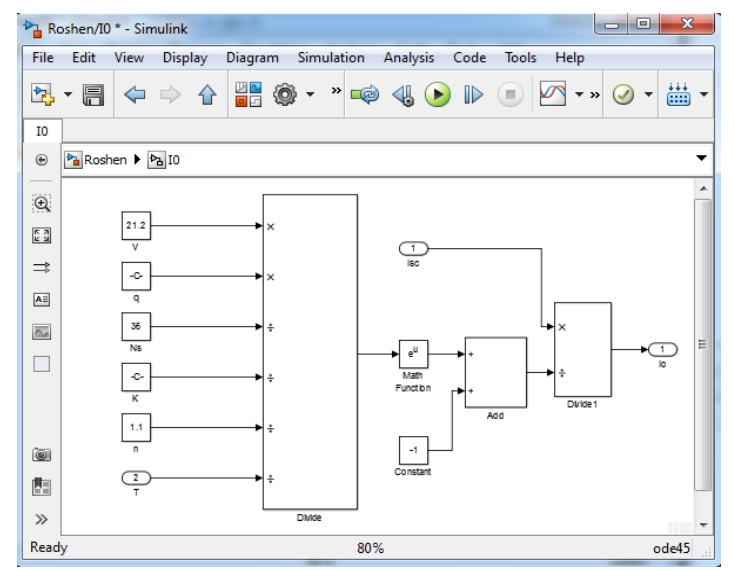

Figure 7 Diode reverse saturation subsystem module

\subsection{SHUNT RESISTANCE CURRENT MODULE ( $\left.\mathbf{I}_{\mathrm{SH}}\right)$}

This block as shown in figure 8 represents shunt resistance current according to equation 9 . The inputs are diode reverse saturation current $(\mathrm{A})$, the temperature $(\mathrm{T})$ in Kelvin and the reference temperature $\left(\mathrm{T}_{\text {ref }}\right)$ in Kelvin's too. The parameters used in this block are electron charge, Boltzman'n constant, band gap for Silicon and diode ideality factor.

The details of this block shown in figure 9, which is the subsystem of the block.

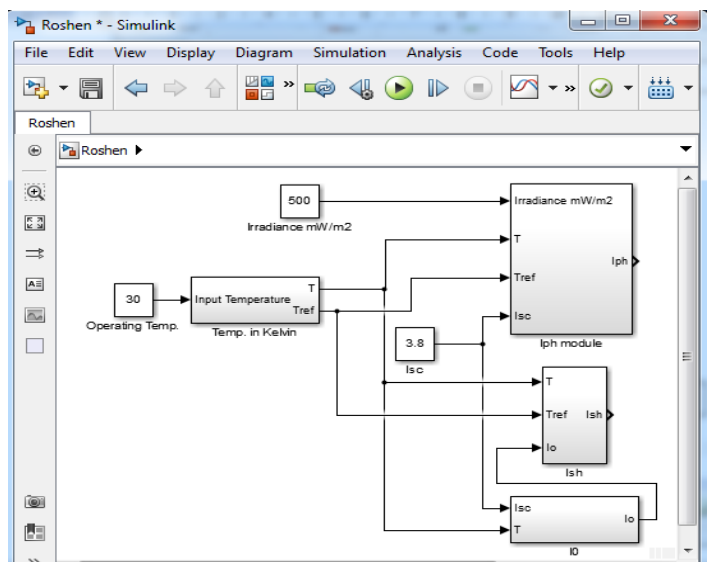

Figure 8 Shunt resistance current module in the system

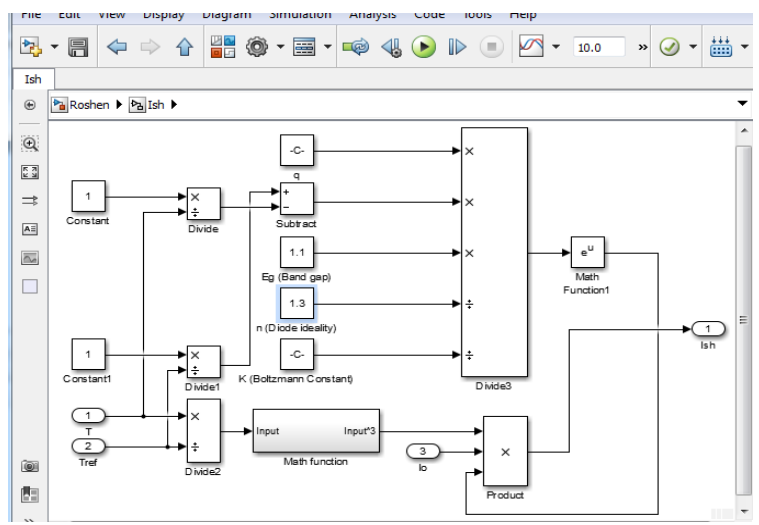

Figure 9 Shunt resistance current subsystem module

\subsection{PHOTOVOLTAIC OUTPUT CURRENT MODULE ( $\left.\mathbf{I}_{\mathrm{PV}}\right)$}

This block represents photovoltaic output current according to equation 10 . The inputs are temperature $(\mathrm{T})$ in Kelvin, short circuit current (A), Photocell current (A) and voltage across the output terminals (volt) while the outputs are photovoltaic current and voltage.

The parameters used in this block are electron charge, Boltzman'n constant, diode ideality factor, number of series and parallel cells and value of series and shunt resistance. The details of this block shown in figure 10 , which is the subsystem of the block. 


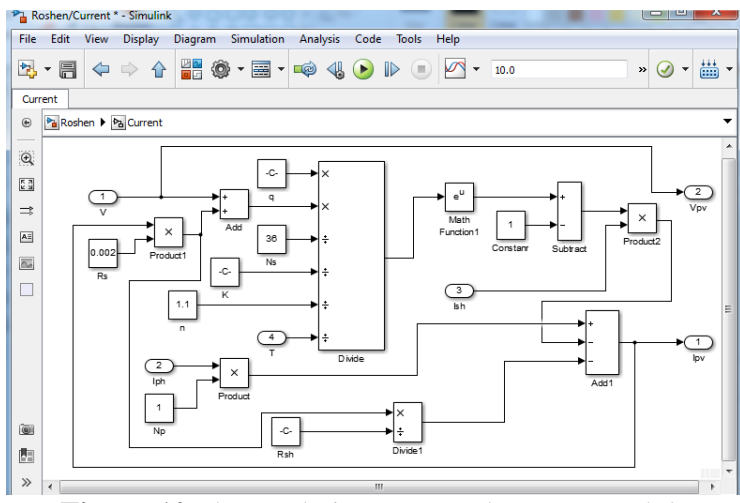

Figure 10 Photovoltaic current subsystem module

Finally, figure 11 shows the overall system module that simulates the Solar cell system.

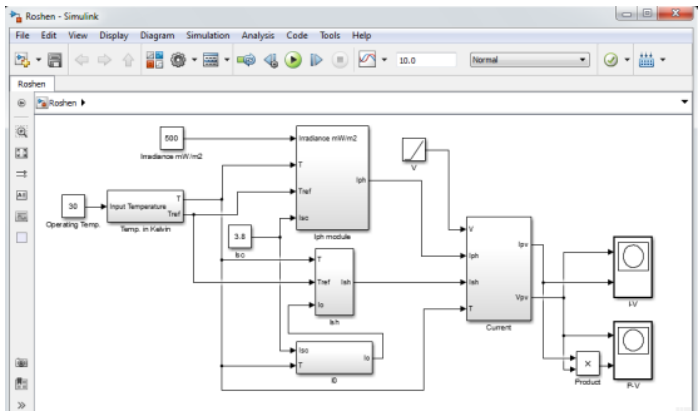

Figure 11 Solar cell system modeling simulation

\section{RESULTS}

In this simulation, solar cell specification curves I-V and $\mathrm{P}-\mathrm{V}$ have been obtained for various irradiance and different operating temperature.

In addition, in this simulation, changing the parameters of table 1 can be done very easily by changing the constants block. These results obtained by using output scope block and to workspace block in Matlab-Simulink.

Figure 12 and 13 shows the I-V curves for different irradiance and different temperature respectively.

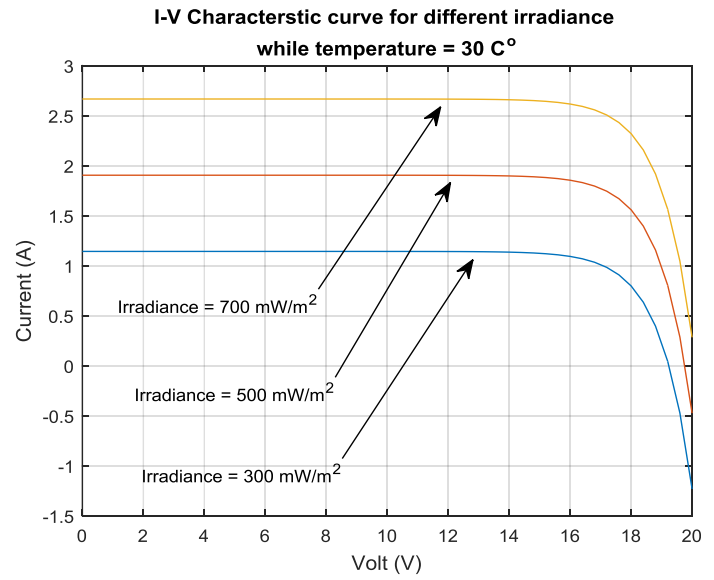

Figure 12 I-V Assorted curves for various irradiance and constant Temperature

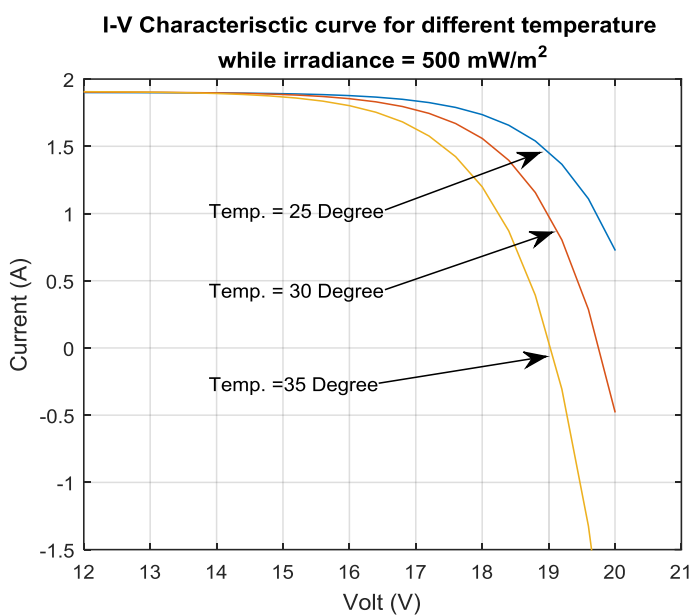

Figure $13 \mathrm{I}-\mathrm{V}$ Assorted curves for various Temperature and constant Irradiance

The effect of increasing irradiance while temperature was fixed $\left(30^{\circ}\right)$ is increasing the output and short circuit current, the output voltage almost not affected very much. In the second test, the output voltage decrease when the operating temperature increase whiles the irradiance was constant $\left(500 \mathrm{~mW} / \mathrm{m}^{2}\right)$.

The third and fourth tests show the P-V curves for different irradiance and operating temperature as shown in figure 14 and 15, increasing the irradiance cause increasing the max power and max peak current, on the other hand increasing temperature cause to reduce the max power and max peak voltage [15].

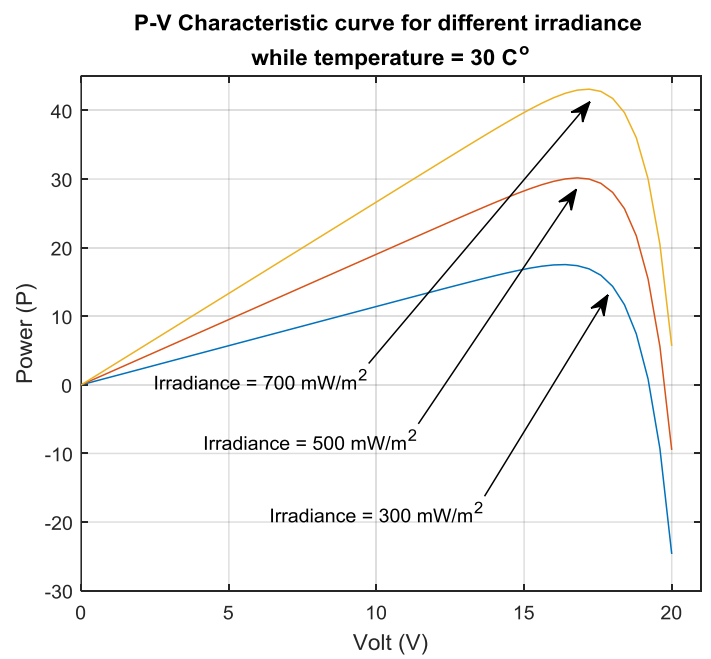

Figure $14 \mathrm{P}-\mathrm{V}$ Assorted curves for various radiation and constant temperature 


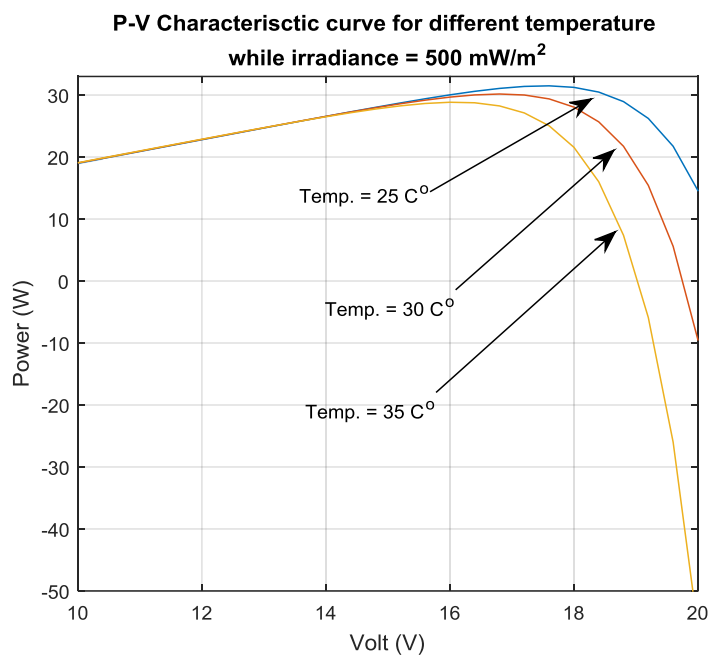

Figure $15 \mathrm{P}-\mathrm{V}$ Assorted curves for various Temperature and constant Irradiance

\section{CONCLUSION}

In this research, Matlab-Simulink used to get the I-V and $\mathrm{P}-\mathrm{V}$ characteristic curves of a solar cell system. These curves used to calculate the specifications of a solar cell system such as short circuit current, open circuit voltage, power and maximum power.

From the experimental results, one can know the parameters that affect the solar cell efficiency and quality such as irradiance and temperature.

This solar cell simulation is a general design so one can change the electrical segments such as resisters, diode and number of parallel and series cells very easily in order to get other solar cell system design.

\section{REFERENCE}

[1] J. Selvaraj, N. A. Rahim, "Multilevel Inverter For Grid-Connected PV System Employing Digital PI Controller", IEEE Transactions On Industrial Electronics,vol. 56, No. 1, pp. 149-158 , 2009.

[2] Advanced Energy: An International Journal (AEIJ), Vol. 1, No. 2, April 2014, "STUDY OF THE EQUIVALENT CIRCUIT OF A DYESENSITIZED SOLAR CELLS", M. Belarbi , A. Benyoucef, B. Benyoucef Research Unit Materials and Renewable Energy, Department of Physics University of Abou Bekr Belkaid-Tlemcen, BP: 119 Tlemcen 13000, Algeria.

[3] B.BA and M.KANE, "Determination of polysilicon solar cell parameters using electrical short-circuit current Decay method", Solid-State Electronics,vol.42,N0.4,pp.541-545, 1998.

[4] A. H. Al-Hamdani, S. I. Ibrahim, and S. K. Abud Alrda, "Effects of Luminous Solar Concentrator Parameters (Dyes Mixture, Host type and LSC Thickness) on the Si Solar Cell Performance Efficiency" , International Journal of Current Engineering and Technology, Vol.5, No.4, pp(24392443), Aug. 2015.
[5] K. Ishaque, Z. Salam, S. Mkhilef, A. Shamsudin, "Parameter extraction of solar photovoltaic modules using penalty-based differential evolution" Applied Energy 99 (2012),297-308.

[6] M. Ö. Yatak, " Fotovoltaik Beslemeli Aralıklı Tip 2 Bulanık Mantık Denetleyicili İki Kademeli Dönüştürücünün Gerçekleştirilmesi”, Elektronik ve Bilgisayar Eğitimi Gazi Üniversitesi Bilişim Enstitüsü Doktora Tezi, 2012, Ankara.

[7] H. Tsai, C. Tu, Yi-Jie Su, "Development of Generalized Photovoltaic Model Using MATLAB/SIMULINK", Proceedings of the World Congress on Engineering and Computer Science WCECS, San Francisco, USA, 2008.

[8] M. Francisco, G. Longatt, "Model of Photovoltaic Module in Matlab ${ }^{\text {TM", }}$ 2do congresor beroamer cano de estudiantes de ingenıeríaeléctrı ca, electrónıcaly computación pp.1-5, 2005.

[9] Ş. Yılmaz, M. Aksu, Z. Özer, H. R. Özçalık, Matlab İle Gerçekleştirilen Fotovoltaik (PV) Güneş Pili Modeli İle Güneş Enerjisi Üretimindeki Önemli Etkenlerin Tespit Edilmesi”, ELECO 2012,Bursa.

[10] S. Rustemli, F. Dincer, "Modeling of Photovoltaic Panel and Examining Effects of Temperature in Matlab/Simulink", Electronics and Electrical Engineering, ISSN 1392-1215, no. 3(109), pp. 35-40, 2011.

[11] O. Gergaud, B. Multon, H. Ben Ahmed « Analysis and Experimental Validation of Various Photovoltaic System Models »7th International ELECTRIMACS Congress, Montréal, Août 2002.

[12] Cubas, J.; Pindado, S.; Victoria, M. "On the analytical approach for modeling photovoltaic systems behavior". Journal of Power Sources 2014, 467-474.

[13] Savita Nema, R.K. Nema, Gayatri Agnihotri,"MATLAB/Simulink based study of photovoltaic cells / modules / array and their experimental verification", International journal of Energy and Environment, vol.1,No.3, pp.487-500, 2010.

[14] O. Shekoofa, M. Taherbaneh, "Modelling of silicon solar panel by matlab/simulink and evaluating the importance of its parameters in a space application" 3rd International Conference on Recent Advances in Space Technologies, 2007. RAST '07 by IEEE.

[15] R. T. Ahmed, "Obtaining and analyzing the characteristics curves of a solar cell", International Journal Of Computation and Applied Sciences IJOCAAS, Vol. 2, Issue 2, ISSN:2399-4509, PP: 9498, April 2017

\section{Biography}

Assistance Lecturer Roshen Tariq Ahmed is working now as a researcher in Energy and Renewable Energies Technology Center in university of technology, his BSc. and MSc. is in Control engineering from University of technology,Baghdad/IRAQ, (https://scholar.google.com/c itations?hl=en\&user=LX4U6nQAAAAJ) is google scholar page, and (http://orcid.org/0000-0002-0042- 
9558) is the ORCID link, and his Research gate link is (https://www.researchgate.net/profile/Roshen_Tariq_Ah med_Hamdi? ev=hdr_xprf\&_sg=uqofbhELluNgQUUdm Fi1QX6tdS-

TPDOxtbPxlJT8blNcEiJhTn9xjMiLSb8vQwm) 